\title{
Sensitivity of Citrobacter freundii and Citrobacter koseri to cephalosporins and penicillins
}

\author{
B. HOlmes, ANNA KING, I. PHillips, AND S. P. LAPAGE \\ From the National Collection of Type Cultures, Central Public Health Laboratory, London, and Department \\ of Microbiology, St Thomas's Hospital Medical School, London
}

SYNOPSIS An examination of 99 field and reference strains of Citrobacter freundii showed $79 \%$ of them to be resistant to cephaloridine and sensitive to carbenicillin, while $96 \%$ of 45 field and reference strains of Citrobacter koseri examined were sensitive to cephaloridine and resistant to carbenicillin. Susceptibility tests with these two antibiotics are therefore useful in separating the two species of Citrobacter.

Werkman and Gillen (1932) proposed the genus Citrobacter and included seven named species of which one was $C$. freundii, a species that today is well established while the other six failed to gain acceptance. Frederiksen (1970) proposed the name Citrobacter koseri for 30 strains that he studied which were closely related to $C$. freundii but differed sufficiently to warrant recognition as a new species. Booth and McDonald (1971) examined 40 similar strains and agreed with Frederiksen that these strains should constitute a new species of the genus Citrobacter.

Ewing and Davis (1972) considered C. koseri to be the same taxon as $C$. diversus (Werkman and Gillen, 1932) and in their view $C$. koseri is thus a junior synonym for $C$. diversus. The original description of C. diversus was, however, based on only two strains which were described as being non-motile, producing acid and gas from inositol, raffinose, and starch, not attacking dulcitol, and having an indeterminate methyl red reaction, characters that are seldom, if ever, possessed by strains of $C$. koseri.

Young, Kenton, Hobbs, and Moody (1971) proposed a new genus, Levinea, for bacteria of the Citrobacter group that fail to produce $\mathrm{H}_{2} \mathrm{~S}$ on triple sugar iron agar (TSI) and divided them into two species, $L$. malonatica (which corresponds to $C$. koseri) and $L$. amalonatica. Previously other strains of the Citrobacter group that failed to produce $\mathrm{H}_{2} \mathrm{~S}$ on TSI agar had been named Padlewskia by Macierewicz (1966); but strains of Padlewskia and L. amalonatica may be atypical strains of Citrobacter freundii that fail to produce $\mathrm{H}_{2} \mathrm{~S}$ on TSI agar and

Received for publication 23 May 1974. produce indole, a biotype described by Ewing and Davis (1971). In the present paper we shall refer to reference strains of $C$. diversus and $L$. malonatica that we have examined as Citrobacter koseri.

The use of cephalosporins in the differentiation of members of the tribe Klebsielleae is well documented. Several authors (Fleming, Goldner, and Glass, 1963; Benner, Micklewait, Brodie, and Kirby, 1965; Koch and Rose, 1966; Ramirez, 1968; Poupard, Dewees, and Morton, 1970; Zabransky, Hall, Day, and Needham, 1969; Sanford, 1969) found strains of Klebsiella generally sensitive and strains of Enterobacter and Serratia resistant to one or other of the cephalosporins (cephalosporin C, cephaloridine, cephalothin). Toala, Lee, Wilcox, and Finland (1970) found their strains of Enterobacter aerogenes and Enterobacter cloacae resistant to cephalothin and cephaloridine, and Wilfert, Barrett, Ewing, Finland, and Kass (1970) found their strains of Serratia highly resistant to cephalosporins.

The use of cephalosporin $C$ in the separation of Citrobacter freundii from strains of Salmonella has been described by Fleming, Charlebois, and Dunmore (1970) who found all 53 of their strains of C. freundii resistant to cephalosporin $C$ while $\mathbf{3 5 0}$ strains of Salmonella were sensitive. Similarly Slocombe and Sutherland (1970) found that their 13 strains of $C$. freundii had minimal inhibitory concentrations of cephaloridine in excess of 12.5 $\mu \mathrm{g} / \mathrm{ml}$.

Booth and McDonald (1971) reported that their strains of $C$. koseri were sensitive to cephaloridine; Smith, Dayton, and Chirps (1973) found their strains of Citrobacter diversus sensitive to cephalothin and resistant to carbenicillin, and Jones, Ragsdale, 
Kutscher, and Sanford (1973) found $93 \%$ of their strains of $C$. diversus were inhibited by $5 \mu \mathrm{g} / \mathrm{ml}$ or less of cephalothin whilst $95 \%$ of $C$. freundii strains tested were resistant to this concentration. Washington, $\mathrm{Yu}$, and Martin (1970), however, found that most of their $\mathrm{H}_{2} \mathrm{~S}$-negative Citrobacter strains were resistant to cephalothin $(96 \%)$ and sensitive to carbenicillin $(80 \%)$. The biochemical results they obtained for their 25 strains, however, suggest that although the strains are $\mathrm{H}_{2} \mathrm{~S}$-negative they correspond more closely to $C$. freundii than $C$. koseri, as most strains $(80 \%)$ failed to produce indole, all grew in $\mathrm{KCN}$ medium, $60 \%$ failed to utilize malonate, and none fermented adonitol. A high proportion ( $76 \%$ ) of their strains decarboxylated ornithine which is unexpected for strains of $C$. freundii. If it is accepted that these strains described by Washington, $\mathrm{Yu}$, and Martin (1970) are $\mathrm{H}_{2} \mathrm{~S}-$ negative variants of $C$. freundii then their antibiotic sensitivity results also accord with the findings of other authors. Slifkin and Engwall (1969) found $93 \%$ of their $\mathrm{H}_{2} \mathrm{~S}$-negative strains, which they classified as Citrobacter intermedium (Werkman and Gillen, 1932), sensitive to cephalothin. Possibly these strains belonged to the $\mathrm{H}_{2} \mathrm{~S}$-negative biotype of $C$. freundii since they were able to grow in $\mathrm{KCN}$ medium and $83 \%$ were sensitive to ampicillin but as these strains were sensitive to cephalothin they were unlike the typical $\mathrm{H}_{2} \mathrm{~S}$-negative strains of $C$. freundii.

\section{Materials and Methods}

Of the 144 strains examined in this study, 54 field strains of Citrobacter freundii and 36 of Citrobacter koseri were isolated in St Thomas' Hospital, London, over a period of three years. A further 22 field strains of $C$. freundii were received for identification by the Computer Trials Laboratory at Colindale. Thirty-two NCTC strains of Citrobacter were examined and included strains listed in the NCTC

\begin{tabular}{|c|c|c|c|c|c|c|c|c|c|c|c|c|c|c|c|}
\hline \multirow[b]{2}{*}{ Group } & \multirow[b]{2}{*}{$\begin{array}{l}\text { No. } \\
\text { of } \\
\text { Strains }\end{array}$} & \multicolumn{3}{|c|}{ Antibiotic Sensitivity } & \multicolumn{5}{|c|}{ Biochemical Tests } & \multicolumn{6}{|c|}{ Distribution of Strains } \\
\hline & & $\begin{array}{l}\text { Cephalo- } \\
\text { ridine } \\
\text { is }\end{array}$ & $\begin{array}{l}\text { Carbeni- } \\
\text { cillin }\end{array}$ & $\begin{array}{l}\text { Ampi- } \\
\text { cillin }\end{array}$ & $\begin{array}{l}\text { Malo- } \\
\text { nate }\end{array}$ & $\begin{array}{l}\text { Argi- } \\
\text { nine }\end{array}$ & Indole & $\begin{array}{l}\text { Orni- } \\
\text { thine }\end{array}$ & $\begin{array}{l}\mathrm{H}_{2} S \\
(T S I)\end{array}$ & $\begin{array}{l}\text { No. Ref- } \\
\text { erence } \\
\text { Strains }\end{array}$ & Designation & $\begin{array}{l}\text { NCTC } \\
\text { Number }\end{array}$ & $\begin{array}{l}\text { No. Field } \\
\text { Strains } \\
\text { from St } \\
\text { Thomas' } \\
\text { Hospital }\end{array}$ & $\begin{array}{l}\text { No. } \\
\text { Field } \\
\text { Strains } \\
\text { from } \\
\text { Other } \\
\text { Sources }\end{array}$ & $\begin{array}{l}\text { Total } \\
\text { Strains }\end{array}$ \\
\hline \multirow[t]{7}{*}{$\mathbf{A}$} & 63 & $\mathbf{R}$ & $\mathbf{S}$ & $\mathbf{S}$ & - & + & - & - & +1 & 6 & $\begin{array}{l}\text { C. ballerupensis } \\
\text { C. freundii }\end{array}$ & $\begin{array}{l}7822^{i} \\
6272\end{array}$ & 12 & 4 & 22 \\
\hline & & & & & - & + & - & - & - & 1 & C. ballerupensis & $s 7820$ & 13 & 0 & 14 \\
\hline & & & & & - & + & - & + & + & 5 & $\begin{array}{l}\text { C. ballerupensis } \\
\text { C. freundii }\end{array}$ & $\begin{array}{l}6021 \\
6269^{11}\end{array}$ & 4 & 9 & 18 \\
\hline & & & & & - & + & - & + & - & 0 & & & 1 & 4 & 5 \\
\hline & & & & & - & + & + & - & + & 0 & & & 1 & 0 & 1 \\
\hline & & & & & - & + & + & - & - & 0 & & & 1 & 0 & $i$ \\
\hline & & & & & - & + & + & + & $\rightarrow$ & 2 & C. freundii & $6266^{11 i}$ & 0 & 0 & 2 \\
\hline \multirow[t]{5}{*}{$\mathbf{B}$} & 15 & $\mathbf{R}$ & $\mathbf{S}$ & $\mathbf{R}$ & - & + & - & - & + & 2 & C. freundii & $8581^{1 v}$ & 7 & 0 & 9 \\
\hline & & & & & - & + & - & - & - & 0 & & & 2 & 0 & 2 \\
\hline & & & & & - & + & - & + & + & 1 & C. ballerupensis & 6848 & 1 & 0 & 2 \\
\hline & & & & & - & - & - & - & + & 1 & C. freundii & 6271 & 0 & 0 & 1 \\
\hline & & & & & - & - & - & - & - & 1 & C. freurdii & 8165 & 0 & 0 & $i$ \\
\hline \multirow[t]{4}{*}{ C } & 12 & $\mathbf{R}$ & $\mathbf{R}$ & $\mathbf{R}$ & - & + & - & - & + & 0 & & & 4 & 0 & 4 \\
\hline & & & & & - & + & + & - & - & 0 & & & 1 & 0 & 1 \\
\hline & & & & & - & + & + & + & - & 2 & L. amalonatica & $10805 v$ & 0 & 4 & 6 \\
\hline & & & & & + & - & - & + & - & 0 & & & 1 & 0 & 1 \\
\hline D & 1 & $\mathbf{S}$ & $\mathbf{R}$ & $\mathbf{R}$ & - & + & + & + & - & 1 & C. freundii & 6071 & 0 & 0 & 1 \\
\hline \multirow[t]{2}{*}{$\mathbf{E}$} & 2 & $\mathbf{S}$ & $\mathbf{R}$ & $\mathbf{S}$ & + & + & - & - & - & 1 & C. freundii & $9094^{2}$ & 0 & 0 & $i$ \\
\hline & & & & & + & - & - & - & + & 0 & & & 1 & 0 & 1 \\
\hline \multirow[t]{4}{*}{$\mathbf{F}$} & 5 & $\mathbf{S}$ & $\mathbf{S}$ & $\mathbf{S}$ & - & + & - & - & + & 0 & & & 1 & 0 & 1 \\
\hline & & & & & - & + & - & - & - & 0 & & & 1 & 0 & 1 \\
\hline & & & & & - & + & - & + & - & 0 & & & 2 & 0 & 2 \\
\hline & & & & & - & + & + & + & - & 0 & & & 0 & 1 & 1 \\
\hline $\mathbf{G}$ & 1 & $\mathbf{S}$ & $\mathbf{S}$ & $\mathbf{R}$ & - & + & - & - & + & 0 & & & 1 & 0 & 1 \\
\hline
\end{tabular}

Table I Biochemical and antibiotic resistance patterns of Citrobacter freundii ${ }^{3}$

${ }^{1}$ Most typical antibiotic sensitivity and biochemical pattern

'Possess Escherichia coli antigens

All strains grow in KCN medium and do not ferment adonitol

Also 7823, 7824, 7829, 8782

"Also $9067^{2}, 9072^{2}, 9122^{*}$

111 Also 6267

ivAlso 9750

vAlso 10806 
catalogue under Citrobacter ballerupensis, $C$. freundii, $C$. diversus, $C$. koseri, Levinia malonatica, and $L$. amalonatica (tables I and II).

All reference strains were tested in the Computer Trials Laboratory in 50 tests described previously (Bascomb, Lapage, Willcox, and Curtis, 1971). A smaller number of tests was performed on all the field strains, using the same methods, at St Thomas' Hospital. Sensitivities of the organisms to ampicillin, carbenicillin, cephalosporin $\mathrm{C}$, and cephaloridine were assessed at St Thomas' Hospital by the determination of minimal inhibitory concentrations (MICs). Suitable concentrations of the antibiotics were incorporated in Diagnostic Sensitivity Test agar (Oxoid CM 261). Inocula consisted of approximately $10^{4}$ organisms and the results were read after overnight incubation at $37^{\circ} \mathrm{C}$. Strains were considered sensitive to ampicillin, carbenicillin, and cephaloridine if the MICs were $10 \mu \mathrm{g} / \mathrm{ml}$ or less and to cephalosporin C if the MICs were $100 \mu \mathrm{g} / \mathrm{ml}$ or less.

\section{Results}

\section{CITROBACTER FREUNDII}

Of 99 strains of Citrobacter freundii, $78(79 \%)$ were resistant to cephaloridine, sensitive to carbenicillin, and either moderately sensitive or resistant to ampicillin (groups A and B, table I). This group of strains comprised 19 of 23 reference strains, 42 out of 54 field strains from St Thomas' Hospital, and 17 of the 22 field strains from elsewhere. Characteristic MICs for this typical pattern were greater than 100 $\mu \mathrm{g} / \mathrm{ml}$ for cephaloridine, 1.25 to $5 \mu \mathrm{g} / \mathrm{ml}$ for carbenicillin, and 5 to $50 \mu \mathrm{g} / \mathrm{ml}$ for ampicillin.

Twenty-one of the strains of Citrobacter freundii showed different sensitivity patterns; 12 were resistant to all three antibiotics and of these four strains were biochemically typical and eight biochemically atypical (group C, table I).

A further three strains were biochemically atypical and showed the sensitivity pattern expected for $C$. koseri (groups D and $\mathrm{E}$, table I), and five other strains were sensitive to all three antibiotics (group F, table I); one of these five strains was biochemically typical but the other four were biochemically atypical. The remaining strain was biochemically typical but sensitive to both cephaloridine and carbenicillin although resistant to ampicillin (group $\mathbf{G}$, table I). Of these nine cephaloridine-sensitive strains, two had cephalosporin C MICs of $25 \mu \mathrm{g} / \mathrm{ml}$, two of $50 \mu \mathrm{g} / \mathrm{ml}$, and the remainder were resistant to cephalosporin C, with MICs of $100 \mu \mathrm{g} / \mathrm{ml}$ or more. The distribution of these strains is given in table $\mathrm{I}$.

\section{CITROBACTER KOSERI}

Forty-three of 45 strains $(96 \%)$ of Citrobacter koseri were sensitive to cephaloridine and resistant to carbenicillin and ampicillin. These comprised all the strains from St Thomas' Hospital and seven of nine reference strains. Characteristic MICs were 1.25 to $5 \mu \mathrm{g} / \mathrm{ml}$ for cephaloridine, greater than 100 $\mu \mathrm{g} / \mathrm{ml}$ for carbenicillin, and 25 to $100 \mu \mathrm{g} / \mathrm{ml}$ for ampicillin. Two of the reference strains had cephaloridine MICs of $25 \mu \mathrm{g} / \mathrm{ml}$ and were classed as resistant, but were sensitive to cephalosporin $C$ and were typical in all other respects (table II).

\section{Discussion}

The findings substantiate the basic division of the genus Citrobacter into two species, $C$. freundii and $C$.

\begin{tabular}{|c|c|c|c|c|c|c|c|c|c|c|c|c|c|c|}
\hline \multirow[b]{2}{*}{ No. of Strains } & \multicolumn{3}{|c|}{ Antibiotic Sensitivity } & \multicolumn{5}{|c|}{ Biochemical Tests } & \multicolumn{6}{|c|}{ Distribution of Strains } \\
\hline & $\begin{array}{l}\text { Cephal- } \\
\text { oridine }\end{array}$ & $\begin{array}{l}\text { Carbeni- } \\
\text { cillin }\end{array}$ & $\begin{array}{l}\text { Ampi- } \\
\text { cillin }\end{array}$ & $\begin{array}{l}\text { Malo- } \\
\text { nate }\end{array}$ & $\begin{array}{l}\text { Argi- } \\
\text { nine }\end{array}$ & Indole & $\begin{array}{l}\text { Orni- } \\
\text { thine }\end{array}$ & $\begin{array}{l}\mathrm{H}_{2} \mathrm{~S} \\
(T S I)\end{array}$ & $\begin{array}{l}\text { No. Ref- } \\
\text { erence } \\
\text { Strains }\end{array}$ & Designation & $\begin{array}{l}\text { NCTC } \\
\text { Number }\end{array}$ & $\begin{array}{l}\text { No. Field } \\
\text { Strains } \\
\text { from St } \\
\text { Thomas' } \\
\text { Hospital }\end{array}$ & $\begin{array}{l}\text { No. } \\
\text { Field } \\
\text { Strains } \\
\text { from } \\
\text { Other } \\
\text { Sources }\end{array}$ & $\begin{array}{l}\text { Total } \\
\text { Strains }\end{array}$ \\
\hline \multirow[t]{3}{*}{43} & $\mathbf{S}$ & $\mathbf{R}$ & $\mathbf{R}$ & + & + & + & + & -1 & 6 & $\begin{array}{l}\text { C. ballerupensis } \\
\text { C. koseri } \\
\text { C. diversus } \\
\text { L. malonatica }\end{array}$ & $\begin{array}{l}7229 \\
10770^{i} \\
10849 \\
10810^{i 1}\end{array}$ & 34 & 0 & 40 \\
\hline & & & & + & + & + & - & - & 1 & C. koseri & 10769 & 0 & 0 & $\mathbf{I}$ \\
\hline & & & & - & + & + & + & - & 0 & & & 2 & 0 & 2 \\
\hline 2 & $\mathbf{R}^{2}$ & $\mathbf{R}$ & $\mathbf{R}$ & + & + & + & + & - & 2 & C. koseri & $10768^{i 11}$ & 0 & 0 & 2 \\
\hline
\end{tabular}

Table II Biochemical and antibiotic resistance patterns of Citrobacter koseri ${ }^{3}$

\footnotetext{
${ }^{1}$ Most typical antibiotic sensitivity and biochemical pattern

sensitive to cephalosporin C

"All strains ferment adonitol and do not grow in $\mathrm{KCN}$ medium

Also 10786

"Also 10811

i1Also 10771
} 
koseri, though individual strains may be difficult to allot to one or the other species by biochemical tests. Tolerance of $\mathrm{KCN}$ and acid production from adonitol show the best correlation (tables I and II). Tests for cephaloridine and carbenicillin resistance are additional aids for their separation, and our findings substantiate those of other workers.

The results also confirm that Citrobacter diversus (Ewing and Davis, 1972), the Citrobacter strains of Booth and McDonald (1971), the Levinea malonatica strains of Young, Kenton, Hobbs, and Moody (1971), and the Citrobacter koseri of Frederiksen (1970) can be considered to belong to the same taxon.

Occasional strains of both taxa may be resistant to both cephaloridine and carbenicillin and both reference strains of Levinea amalonatica that we examined fell into this category. One reference strain of $C$. freundii and five field strains from sources other than St Thomas' Hospital were biochemically identical to the two reference strains of $L$. amalonatica that were examined. This reference strain of $C$. freundii showed the sensitivity pattern expected for strains of $C$. koseri (group D, table I) and one field strain was sensitive to all three antibiotics (group F, table I); however, both were resistant to cephalosporin $\mathrm{C}$. The remaining four strains were resistant to both cephaloridine and carbenicillin (group C, table I). If this dual resistance were observed in additional isolates conforming to $L$. amalonatica then this would be a further useful character in distinguishing $L$. amalonatica from $C$. koseri, and from $C$. freundii if it is sufficiently different from this organism to warrant specific status as Citrobacter amalonatica. Field strains of Levinea amalonatica, however, do not appear to be very common in Europe; the five included in this paper were all that we received among 170 strains of Citrobacter isolated in the UK and sent to the Computer Trials Laboratory for identification. Richard, Brisou, and Lioult (1972) also found only eight strains among 63 strains of the genus Levinea of European or African origin that they examined.

As the field strains from St Thomas' Hospital were isolated over a period of three years during which cross-infection appears to have been minimal, and field strains of $C$. freundii from other sources and reference strains of both taxa in general possess the same patterns of antibiotic resistance it does not appear likely that a single strain has been repeatedly investigated. The wide range of biochemical patterns observed would support this conclusion. However, typical strains may acquire resistance, presumably by resistance transfer, and this may account for the finding of occasional strains of $C$. freundii resistant to carbenicillin. Successful transfer of carbenicillin resistance to a strain of Escherichia coli from four biochemically typical strains of $C$. freundii recently isolated from St Thomas' Hospital (in group C, table I) has been carried out by Slocombe and Sutherland (1974) who were unable, however, to transfer carbenicillin resistance from two of their own strains of $C$. freundii isolated some years ago.

The determination of ampicillin sensitivities did not help to distinguish $C$. freundii from $C$. koseri since $C$. freundii is usually only marginally more sensitive with MICs of the order of 10 to $25 \mu \mathrm{g} / \mathrm{ml}$, whereas C. koseri has ampicillin MICs of 25 to 50 $\mu \mathrm{g} / \mathrm{ml}$. Similarly, the determination of cephalosporin $\mathrm{C}$ in addition to cephaloridine MICs contributed little. Five strains of $C$. freundii sensitive to cephaloridine were resistant to cephalosporin C with MICs of 100 $\mu \mathrm{g} / \mathrm{ml}$ or more, but a further four cephaloridinesensitive strains were also sensitive to cephalosporin C with MICs of 25 to $50 \mu \mathrm{g} / \mathrm{ml}$. The two field strains of $C$. koseri with cephaloridine MICs of $25 \mu \mathrm{g} / \mathrm{ml}$, and classed therefore as resistant, had cephalosporin $\mathrm{C}$ MICs of $50 \mu \mathrm{g} / \mathrm{ml}$ and were thus classed as sensitive. A typical result would therefore have been obtained for seven of these 11 strains by the use of cephalosporin $\mathrm{C}$ rather than cephaloridine, but the results would still have been atypical for the other four strains.

We would like to thank the Department of Health and Social Security whose grant for the identifica? tion of bacteria using a computer enabled us to carry out the work at Colindale. We also thank Beecham Research Laboratories for their support of the work at St Thomas' Hospital. Our thanks are also due to those laboratories that sent us field strains of Citrobacter freundii.

\section{References}

Bascomb, S., Lapage, S. P., Willcox, W. R., and Curtis, M. A. (1971). Numerical classification of the tribe Klebsielleae. J. gen. Microbiol., 66, 279-295.

Benner, E. J., Micklewait, J. S., Brodie, J. L., and Kirby, W. M. M. (1965). Natural and acquired resistance of Klebsiella-Aerobacter to cephalothin and cephaloridine. Proc. Soc. exp. Biol. (N.Y.), 119, 536-541.

Booth, E. V., and McDonald, S. (1971). A new group of Enterobacteria, possibly a new Citrobacter sp. J. med. Microbiol., 4, 329-336.

Ewing, W. H., and Davis, B. R. (1971). Biochemical Characterization of Citrobacter freundii and Citrobacter diversus. Center for Disease Control, Atlanta, Georgia.

Ewing, W. H., and Davis, B. R. (1972). Biochemical characterization of Citrobacter diversus (Burkey) Werkman and Gillen and designation of the neotype strain. Int. J. syst. Bact., 22, 12-18.

Fleming, P. C., Charlebois, M., and Dunmore, R. T. (1970). The use of cephalosporin $\mathbf{C}$ in the identification of Enterobacteriaceac. Postgrad. med. J., 46, Suppl. (October), 51-54.

Fleming, P. C., Goldner, M., and Glass, D. G. (1963). Observations on the nature, distribution, and significance of cephalosporinase. Lancet, 1, 1399-1401.

Frederiksen, W. (1970). Citrobacter koseri (n.sp.) a new species within the genus Citrobacter, with a comment on the taxonomic position of Citrobacter intermedium (Werkman and Gillen). Spisy prir. Fak. Univ. Brně, 47, Ser. K., pp. 89-94.

Jones, S. R., Ragsdale, A. R., Kutscher, E., and Sanford, J. P. (1973). 
Clinical and bacteriologic observations on a recently recognised species of Enterobacteriaceae, Citrobacter diversus. J. infect. Dis., 128, 563-565.

Koch, M. L., and Rose, H. D. (1966). Resistance of the KlebsiellaAerobacter-Serratia division to cephalothin and ampicillin. Amer. J. clin. Path., 46, 589-593.

Macierewicz, M. (1966). A proposal of a new group (genus) of Enterobacteriaceae. (Polish) Med. dośw. Mikrobiol., 18, 337-343. (Translation in Exp. med. Microbiol., 18, 333-339).

Poupard, J. A., Dewees, L. B., and Morton, H. E. (1970). Antibiotic susceptibility of Klebsiella-Enterobacter as determined by a single high-concentration disc method. Antimicrob. Agents Chemother., 489-494.

Ramirez, M. J. (1968). Differentiation of Klebsiella-Enterohacter (Aerobacter)-Serratia by biochemical tests and antibiotic susceptibility. Appl. Microbiol., 16, 1548-1550.

Richard, C., Brisou, B., and Lioult, J. (1972). Etude taxonomique de 'Levinea', nouveau genre de la famille des entérobactéries. Ann. Inst. Pasteur, 122, $1137-1146$.

Sanford, J. P. (1969). Sensitivity tests of Klebsiella, Enterobacter, and Serratia. J. infect. Dis., 119, 388-390.

Slifkin, M., and Engwall, C. (1969). The clinical significance of Citrobacter intermedium. Amer. J. clin. Path., 52, 351-355.

Slocombe, B., and Sutherland, R. (1970). $\beta$-lactamase activity and resistance to ampicillin, carbenicillin, and cephaloridine of
Klebsiella, Enterobacter, and Citrobacter. Antimicrob. Agents Chemother. 1969, 78-85.

Slocombe, B., and Sutherland, R. (1974). Personal communication.

Smith, R. F., Dayton, S. L., and Chirps, D. D. (1973). Recognition of Citrobacter diversus in the clinical laboratory. Appl. Microbiol., 25, 157-158.

Toala, P., Lee, Y. H., Wilcox, C., and Finland, M. (1970). Susceptibility of Enterobacter aerogenes and Enterobacter cloacae to 19 anti-microbial agents in vitro. Amer. J. med. Sci., 260, 41-55.

Washington, J. A., II, Yu, P. K.W., and Martin, W. J. (1970). Hydrogen sulfide-negative variant of Citrobacter. Appl. Microbiol., 20, 587-589.

Werkman, C. H., and Gillen, G. F. (1932). Bacteria producing trimethylene glycol. J. Bact., 23, 167-182.

Wilfert, J. N., Barrett, F. F., Ewing, W. H., Finland, M., and Kass, E. H. (1970). Serratia marcescens: biochemical, serological, and epidemiological characteristics and antibiotic susceptibility of strains isolated at Boston City Hospital. Appl. Microbiol.. $19,345-352$.

Young, V. M., Kenton, D. M., Hobbs, B. J., and Moody, M. R. (1971). Levinea, a new genus of the family Enterobacteriaceae. Int. J. syst. Bact., 21, 58-63.

Zabransky, R. J., Hall, J. W., Day, F. E., and Needham, G. M. (1969). Klebsiella, Enterobacter, and Serratia: biochemical differentiation and susceptibility to ampicillin and three cephalosporin derivatives. Appl. Microbiol., 18, 198-203. 